\title{
Measuring Behavior and Risk Perception to Inform Children's Exposure Assessments and Communication Strategies
}

\author{
Alma Anides Morales \\ The University of Arizona \\ Diego Huerta \\ The University of Arizona \\ Monica Ramirez-Andreotta ( $\nabla$ mdramire@arizona.edu ) \\ University of Arizona https://orcid.org/0000-0001-6220-5763
}

\section{Research article}

Keywords: exposure science, risk perception, sanitation, mouthing behavior, border, risk communication

Posted Date: April 20th, 2021

DOI: https://doi.org/10.21203/rs.3.rs-433981/v1

License: @ (i) This work is licensed under a Creative Commons Attribution 4.0 International License. Read Full License 


\section{Abstract}

Background: Waste management challenges, including transboundary sanitary sewage overflows (SSOs), have continuously been of concern along the US-Mexico border region. Sewage contamination contains high concentrations of pathogens excreted in human and animal feces increasing health-related risks and hindering quality of life. Limited literature exists on environmentally related risk perception studies in rural border town thus we aim to better understand risk perception in a rural border town school community after experiencing adjacent sewage effluent.

Methods: This paper aims to characterize students' spatial behavior and hand/object-to-mouth patterns to inform a risk assessment. Risk assessments often use published human behavior parameter values that may not be culturally or geographically representative. Parents and school staff were surveyed during several school events and provided with a link to an online survey.

Results: Reported student behavior show a lower hand/object-to-mouth frequency for children ages 4-11, and a wider range of hand-to-mouth frequency for students ages 12-16, when compared to other values in the literature. Offensive odors, negative feelings, and general concerns mainly using informal language were frequently cited.

Conclusions: Findings suggest a lack of information and understanding around SSOs, as well as a lack of communication, could contribute to a perceived low-risk or uncertainty around these events. Risk perception is a critical factor of vulnerability, thus effectively disseminating culturally appropriate risk information is an important part in decreasing exposure.

\section{Background}

The states of Sonora, Mexico and Arizona, United States (U.S.) share a 583-km international border and are part of the broader U.S.-Mexico border region defined as $100 \mathrm{~km}$ north and south of the boundary as per the 1983 La Paz Agreement (US EPA, 1983). The towns of Naco, in Cochise County Arizona and Naco, Sonora (collectively known as Ambos Nacos) sit along this political boundary demarked by a physical fence but joined in strong historical ties and shared natural resources and interests. Ambos Nacos sit on a flat-lying alluvial plain with the Mule Mountains to the North and East, and the Sierra San José Mountains to the South (Littin, 1987). Ambos Nacos are located within the binational San Pedro Aquifer and northward flowing San Pedro River which provide water resources and sustain a riparian ecosystem (Callegary et al., 2016). This region is characterized by an arid to semi-arid climate with summer temperatures reaching above $38^{\circ} \mathrm{C}$. Precipitation occurs during the summer and winter months, however the greatest rainfall intensity occurs midJune through October as part of the North American monsoon (Callegary et al., 2016). Not unlike the rest of the border region, climate change projections show a decline in summer precipitation, extended droughts, and hotter temperatures with direct 1910-2010 observations in Cochise County showing a maximum daily temperature increase between 2.0 and $3.6^{\circ} \mathrm{C}$ (Callegary et al., 2016; Garfin et al., 2013; GNEB, 2016; LaraValencia et al., 2013; Shamir et al., 2014). Differences in both countries' governing structures, resources, standards, and priorities present challenges and opportunities in tackling issues facing the border; conditions caused by climate change are expected to contribute to management difficulties and additional 
environmental, social, and economic vulnerability (Callegary et al., 2016; Garfin et al., 2013; GNEB, 2016; LaraValencia et al., 2013; Normal et al., 2012; Shamir et al., 2014).

Communities along the border have historically faced environmental health hazards related to inadequate infrastructure and poor sanitation services (ADEQ \& CEDES, 2018; BHC, 2015; US GAO 2009). In Ambos Nacos, transboundary untreated wastewater flows are first documented in the late 1970s (Beal, 1977). During summer monsoon and winter rains, elevated storm water flows create an overstrain on wastewater collection and treatment systems in Naco, Sonora which can result in sanitary sewage overflows (SSOs) typically observed bi-annually or at times quarterly in Naco, Arizona. At the time this was written, the most recent SSOs occurred at the end of 2018.

During a 2018 SSO event in Naco, Arizona, an untreated municipal sewage effluent flowed past the political boundary and parallel to Naco Elementary school eventually making its way into the arroyo where it followed its natural course to the San Pedro River. Discharge of up to 250,000 gallons per day continued for approximately a month. Cochise Health and Social Services (CHSS) Environmental Health team responded to the raw sewage flow by collecting direct grab samples and sending them to the Arizona Department Environmental Quality (ADEQ) laboratories. All seven samples tested positive for Total Coliforms and E. coli bacteria. Water and soil polluted by fecal contamination is a public health concern due to the high concentrations of enteric pathogens excreted from human and animal feces. Fecally transmitted bacteria, viruses, protozoans, and helminths are associated with gastrointestinal illness, trachoma, and negative nutritional outcomes (Gerba et al., 2006). CHSS declared a State of Emergency and the obtained funds were used to provide immunization clinics to Naco, Arizona residents to protect against hepatitis $A, B$, and tetanus. Furthermore, soil berms were built to contain the pooled water and chlorine tablets were added for disinfection.

Despite the conducted local efforts, concerns remained regarding SSO causes related to infrastructure, effective communication, long-term environmental impacts, health risks, and risk perception among the community. Rural and smaller border communities often lack the resources, administrative support, and technical expertise to access appropriate federal programs that could provide the resources to address these concerns (GNEB, 2016). Thus, partnerships present valuable opportunities to find solutions to complex problems where resources are scarce or where a low level of confidence in government institutions exists (Austin, 2004). The work presented in this paper is a result of a collaborative effort between CHSS, Naco Elementary School, and the University of Arizona Environmental Science (UA ENVS) department. This paper presents the results of written surveys conducted with the Naco Elementary School community including parents, teachers, and principal, to gain insights on: a) child hand/object-to-mouth behavior to supplement human behavior data in a risk assessment (Anides Morales et al., 2020) and b) better understand risk perception and communication preferences to produce translational research and assist CHSS in SSO related actions. As defined by the National Institutes of Health, translational research seeks to convert environmental health research findings into tools, information, and resources that are culturally relevant, specific to the local community, and can be applied by healthcare providers (O'Fallon et al., 2000; Ramirez-Andreotta et al., 2014).

\section{Methods}




\subsection{Building partnerships}

Naco, Arizona is an unincorporated community of approximately 1,000 residents in Cochise County. It has one public school of 270 students, where 150 of them come from Naco, Sonora. The school is directly across the Naco Point of Entry where many families cross by foot. After an initial meeting between CHSS and UA ENVS, the two parties met with Naco Elementary school's principal. The school principal showed a plot of land with harshly deteriorated garden beds. Efforts to rebuild the school garden and construct a nature pathway along with a kiosk by the track, had been halted due to concerns of possible microbial contamination due to SSOs. The study's objectives and methodology, which included the aforementioned behavioral and perception study as well as a quantitative microbial risk assessment for the students, were presented at the Naco School Board meeting. At this meeting, they motioned to approve their collaboration and approved the taking of samples within school premises.

Successful partnerships require an input of time, energy, shared goals, and trust; furthermore, due to the complexity and wide-ranging impacts of environmental problems, collaborative partnerships should engage participants and decision-makers from all sectors and levels (Austin, 2004). In an effort to build trust and engage teachers and students, UA ENVS provided informal science education activities during the Naco Elementary Summer School Program. Providing inquiry-based science activities and working directly with teachers and students presented a valuable opportunity in emphasizing the importance of environmental quality and health. To our knowledge, it was the first collaboration between the University of Arizona and Naco Elementary School, and teachers expressed their support to continue the collaboration.

\subsection{Survey}

\subsubsection{Survey design}

Once the partnership was established, the study was submitted to the University of Arizona's Human Subjects Protection Program and approved by the University of Arizona's Institutional Review Board (IRB). Study participants (principal, teachers, and parents) were consented under the University of Arizona IRB as an approved project. Three different surveys were designed for Naco Elementary School's principal, teachers, and parents (supplementary information 1,2,3). Surveys, the consent form, and other informational materials were available in English and Spanish. Parties were asked about risk perception and awareness around SSOs near the school. They were asked to report whether they had been aware of SSOs near the elementary school, how they found out about such events, and the timeliness of this information. Furthermore, they were asked about their observations, concerns, and actions taken as a result of SSOs. Parents were also asked what other information they would need to decide whether they should be concerned with sewage overflows. The principal survey included questions about school land use prior to the construction of the school and school actions taken in response to SSOs. All three parties were asked about preferences for receiving risk communication and environmental health information.

Both teacher and parent surveys included questions on hand/object-to-mouth frequency to garner information on students' incidental soil ingestion. Parents were asked to recall this information for each child member in their family, while teachers were asked to report on their class' collective behavior. Mouthing and hand contact 
frequencies were classified as events/hour into 5 categories: never (0), seldom (0-15), sometimes (16-30), often (31-50), and always (51+), based on Beamer et al. (2012), where a range for hand-to-mouth frequency for children aged 7-12 was found to be $0.8-60.4$ events/h. The same ranges were used for contact frequency with toys, natural objects (i.e. rocks, plants, soil), and surfaces (i.e. handrails, tables).

It was of interest to determine the locations where students congregate outside the classroom. Using maps of the school property and surrounding areas, teachers were asked about students' activities during, before, and after school, the location of where these took place, and the average time a student spent outside per school day. Activities were categorized as physical or active (running, sport team games) and as passive or resting (reading, listening to music), as the type of activity can affect soil adherence and thus dermal exposure to soil (US EPA, 2009). Teachers were also asked whether any preventative measures are taken to minimize tracking soil into the classroom. The parent survey included questions around student transportation to and from school. Parents who indicated their child(ren) walked to school were also given a map of the school and the surrounding areas to mark the route their child(ren) took to get to school.

\subsubsection{Survey distribution}

All Consent Forms and surveys were available in hard copy and online via Qualtrics software (Qualtrics ${ }^{\mathrm{XM}}$, Provo, UT, 2019). Written consent (hand written or electronically) was obtained by participants (principal, teachers, and parents) over the age of 18 (children were not included in the study). To engage parents, UA ENVS was present during the Naco Elementary School's Back to School Night to jump start the beginning of the 2019-2020 academic school year. Parents in attendance were provided with a one-pager (supplementary information 4) detailing the study's background and objectives. Parents who consented to participate, were provided with an option of a paper or online survey in either English or Spanish. A project's researcher was always available for assistance. Parents also had the option to have a survey link emailed to them to complete at a later time. While parents completed the survey, children were engaged with age-appropriate science activities provided by the UA's Arizona Project Water Education for Teacher's (WET)-Tucson Education program. UA ENVS returned during parent teacher conferences later during the school year and attended a school basketball game concurrently happening in hopes of increasing parent participation.

As recommended by the school principal, teachers were sent an email that included the study introduction, and link to the online consent form and survey.

\subsubsection{Data analysis}

All surveys that were completed online via Qualtrics and were exported as Excel (Microsoft Office Excel 2019, Redmond, WA) files. Paper survey responses were transcribed and entered into Excel. Qualitative coding was performed based on established literature (Creswell and Poth, 2017) and open-ended responses were reviewed by the graduate and undergraduate student researchers $(\mathrm{N}=3)$. A coding scheme was created to capture the major themes mentioned across answers from parents, teachers, and the principal. Coding schemes were reviewed by the supervising researcher and changes were made as agreed upon. A random subset of thirtyeight survey responses were selected, coded, and compared across the graduate student, undergraduate student, and lab manager. Differences were discussed during meetings and clarifications or changes were made to the codebook as needed. 
Survey answers were analyzed and coded in Excel (Microsoft Office Excel 2019, Redmond, WA). Chi-square tests were conducted in RStudio (RStudio Team, Boston, MA, 2019) to determine significant differences between parents' and teachers' answers related to students' hand/object-to-mouth behavior, and to explore differences among risk communication preferences and risk perception among primary household language (supplementary Information 5).

\section{Results}

\subsection{Demographic data from parent surveys}

A total of thirty-one parent surveys were collected with twenty-two (71\%) completed online and nine (29\%) paper responses. Twenty-four (77\%) of the thirty-one respondents chose the English-language survey and seven (23\%) chose Spanish. Parents reported having one (51\%), two (43\%), or three (6\%) child(ren) attend Naco Elementary School. Age and gender distribution of reported students are provided in Fig. 1a and 1b.

Although basic demographic questions were asked in the parent survey, these were optional. Only one response was received regarding the ethnicity of the student (White/Caucasian), and ten responses regarding the ethnicity of the survey responder (6 Latinx /Hispanic; 1 Latinx/Hispanic and White/Caucasian; 3 White/Caucasian). Furthermore, sixteen respondents provided information on their household's income. Per the Cochise County Housing Authority 2019 income limits, twelve reported living in households designated as "low-income" or below.

Location and language related questions had a better response rate $(n=30)$. Most participants reported their home zip code as the one in Naco, AZ (77\%). Other answers included zip codes in Bisbee, AZ (20\%), and Bowie, AZ (3\%). Responses to highest level of education completed were: bachelor's degree (13\%), technical program or technical school (13\%), some college (30\%), high school (37\%), and middle school (3\%). Fifty-three percent reported English as the primary language $(P)$ spoken in their home and Spanish as the secondary language (S), while 27\% reported the opposite (primarily Spanish and English as the secondary language). Monolingual homes were reported as 10\% each (English-only or Spanish-only), see Fig. 2.

\subsection{Exposure data from parent and teacher survey}

Eight online teacher survey responses were received, although six were completed in their totality. All eight respondents reported on various activities done outside and the location around the school in which these are conducted (see Fig. 3a and $3 b$ ). Locations B and C were each cited equally (6 times each) as the top two locations where students spend their time during lunch. Eighty-eight percent of teacher respondents confirmed physical activities are conducted outside, for which location B was mentioned the most overall $(n=18)$, followed by $D(n=17)$, and $C(n=15)$. Sixty-three percent of teachers affirmed students engage in passive activities outside, with location B being cited the most $(n=14)$ followed by $A(n=8)$, and C $(n=6)$. Further breakdown of activities and their locations are shown in Fig. 4a and 4b. Additionally, four teacher surveys reported that students spend 30 minutes outside on average per school day.

Given a different map (Fig. 5a), teachers also reported where their students congregate before and after school (Fig. 5b). They cited locations A, B, C, and D. These answers are congruent with parents' responses, 
where $49 \%$ stated that their child gets dropped off in a car to school, $11 \%$ rides the school bus, and $40 \%$ walk to school. Five out of the 14 parents who mentioned their child(ren) walk to school, traced on the map the general route their child takes to get to school. Four out of the five parents traced along locations $A, B$, and $D$.

Six teachers and 31 parents reported on students' hand/object-to-mouth behavior. Their answers were graphed and compared (Fig. 6). When parent and teacher responses are combined, "never" is the most frequently chosen category for surfaces, natural objects, and toys. However, "seldom" is most often cited for hands. Chi-square tests revealed there was no association between party (i.e. teacher or parents) and frequency responses, although it is important to acknowledge parents reported on each child's behavior, whereas teachers reported on their classroom behavior as a whole.

Table 1 shows the breakdown of parents' observed frequency responses by children's age group. The most often cited frequencies for hand-to-mouth observations was "never" (38\%) and "always" (31\%) for children ages 4-6, "seldom" (39\%) for students 7-11 years old, and "never", "seldom", and "sometimes" were chosen equally (33\% each) for 12-16-year-old students. Chi-squared tests showed there was no association between object (hands, toys, natural objects, or surfaces) and the reported frequency. 
Table 1

Parent responses $(\mathrm{N}=31)$ describing their child(ren)'s hand/object-to-mouth behavior by age group.

\begin{tabular}{|c|c|c|c|c|c|}
\hline $\begin{array}{l}4-6 \\
\text { years }\end{array}$ & $\begin{array}{l}\text { Never } \\
\text { (0 times } \\
\text { per hour) }\end{array}$ & $\begin{array}{l}\text { Seldom } \\
(0-15 \text { times } \\
\text { per hour) }\end{array}$ & $\begin{array}{l}\text { Sometimes ( } 16-30 \\
\text { times per hour) }\end{array}$ & $\begin{array}{l}\text { Often } \\
\text { (31-50 times } \\
\text { per hour) }\end{array}$ & $\begin{array}{l}\text { Always } \\
(51+\text { times } \\
\text { per hour) }\end{array}$ \\
\hline Hands & $38 \%$ & $19 \%$ & $6 \%$ & $6 \%$ & $31 \%$ \\
\hline Toys & $44 \%$ & $19 \%$ & $13 \%$ & $6 \%$ & $19 \%$ \\
\hline $\begin{array}{l}\text { Natural } \\
\text { Objects }\end{array}$ & $56 \%$ & $13 \%$ & $6 \%$ & $6 \%$ & $19 \%$ \\
\hline Surfaces & $50 \%$ & $13 \%$ & $6 \%$ & $6 \%$ & $25 \%$ \\
\hline \multicolumn{6}{|l|}{$\begin{array}{l}7-11 \\
\text { years }\end{array}$} \\
\hline Hands & $22 \%$ & $39 \%$ & $22 \%$ & $9 \%$ & $9 \%$ \\
\hline Toys & $46 \%$ & $29 \%$ & $4 \%$ & $17 \%$ & $4 \%$ \\
\hline $\begin{array}{l}\text { Natural } \\
\text { Objects }\end{array}$ & $57 \%$ & $13 \%$ & $17 \%$ & $9 \%$ & $4 \%$ \\
\hline Surfaces & $52 \%$ & $26 \%$ & $4 \%$ & $13 \%$ & $4 \%$ \\
\hline \multicolumn{6}{|l|}{$\begin{array}{l}12-16 \\
\text { years }\end{array}$} \\
\hline Hands & $33 \%$ & $33 \%$ & $33 \%$ & $0 \%$ & $0 \%$ \\
\hline Toys & $80 \%$ & $0 \%$ & $20 \%$ & $0 \%$ & $0 \%$ \\
\hline $\begin{array}{l}\text { Natural } \\
\text { Objects }\end{array}$ & $80 \%$ & $20 \%$ & $0 \%$ & $0 \%$ & $0 \%$ \\
\hline Surfaces & $60 \%$ & $20 \%$ & $20 \%$ & $0 \%$ & $0 \%$ \\
\hline
\end{tabular}

\subsection{Risk perception}

Themes cited more than once by parents when describing sewage overflows are detailed in Table 2.

Descriptions mainly used informal language such as "gross" and "bad", and overwhelmingly described these events as unpleasant and associated them with contamination. Answers that used more formal language mostly referred to the infrastructural causes of SSOs (i.e. sewage treatment facilities, proper equipment). If the answer cited consequences of SSOs, these often referred to general risks (i.e. "big problem") rather than to specific health-related risks. When parents were asked if they were concerned about SSOs in their community $48 \%$ responded they were not or were not sure. Similarly, $55 \%$ do not change their daily routine during these events (see Fig. 7). Parents who do report making changes (45\%) primarily do so to limit environmental exposures and improve sanitary practices. Some examples are handwashing, staying indoors, avoiding the problem area, and providing their own water source (Table 3). Twenty-six percent of parent respondents cited needing more information in order to know if they should be concerned (Table 4); this includes the following forms of information: general, health-related, and water quality (not shown in Table 4 as it was cited once). 
Chi-squared tests revealed no association between primary household language and whether parents had concerns, or whether any changes were made during SSO events. 
Table 2

Themes reported by parents when asked: "What does a SSO mean to you?".

\section{Parent Code: Negative \\ Feelings}

\section{Child Code}

Example of Child Code

\# of

Parents

Citing

$(\mathrm{N}=$

31)

Unpleasant

The pestilence is very unpleasant and the dirty waters*

10

Contamination

It's dirty water that can harm this town

10

Observations

Bad and smells very bad

4

Parent Code:

Consequences of SSOs

Child Code

Example of Child Code

\# of

Parents

Citing

$(\mathrm{N}=$

31)

General risks
Risks to health
Parent Code:
Operational/Infrastructure
causes of SSOs

Child Code

Example of Child Code

\# of

Parents

Citing

$(\mathrm{N}=$

31)

Operational causes

No more space in the sewage starts to flow out into the streets

9 and community

Parent Code: Description

Child Code

Example of Child Code

\# of

Parents

Citing

$(\mathrm{N}=$

31)

Informal

Nasty water coming out of its usual space

18 


\section{Parent Code: Negative}

Feelings

High informal

when the proper equipment fails on how to spread things around or enough room for the population on each town is not calculated and pipes start bursting and things overflows to different places

*answer was translated from Spanish to English

Table 3

Themes reported by parents when asked: "What changes do you make during SSOs?".

\section{Parent Code: None stated}

Child Code

Example of Child Code

\# of Parents

Citing

$(\mathrm{N}=31)$

None

None

16

Parent Code: Experience

mitigation

Child Code

Example of Child Code

\# of Parents

Citing

$(\mathrm{N}=31)$

Sanitation

Make them cover their mouths

4

Environmental exposures

Extremely careful when walking or touching

9 things

Alternative drinking water

Drinking from water bottles 
Table 4

Themes reported by parents when asked: "What additional information would you need to decide whether or not to be concerned with SSOs?".

\begin{tabular}{|llc|}
\hline $\begin{array}{l}\text { Parent Code: None } \\
\text { stated }\end{array}$ & Example of Child Code & (N=31) \\
\hline Child Code & None & 2 \\
\hline Cone & & Citing \\
\hline $\begin{array}{l}\text { Parent Code: More } \\
\text { information }\end{array}$ & Example of Child Code & \# of Parents \\
\hline Child Code & & Citing \\
\hline General information & Just knowledge of it even happening & $(\mathbf{N}=31)$ \\
\hline Regarding health & $\begin{array}{l}\text { what may be the... health issues? Concern pertains in my } \\
\text { family's safety in all }\end{array}$ & 2 \\
\hline
\end{tabular}

Twenty-three parents, three teachers, and the school principal provided their observations during SSOs (Table 5). The most frequently cited observations are 1) smell, 2) feeling upset, and 3) visual observations. Half of those who mentioned visual observations noted the signs and barricades that are often placed. One answer specifically mentions CHSS, "medidas que ha tomado el condado de Cochise" (measures taken by Cochise County). Only one parent and one school staff member cited taking personal actions. When asked to describe concerns related to SSOs, parents emphasize the health and safety of their community and children. Three school staff members expressed concerns regarding health, and two expressed concerns about potential water contamination (Table 6). 
Table 5

Themes reported by parents, and teacher and principal surveys (school staff) when asked: "What observations have you made during a SSO event?".

\section{Parent Code: Observations}

Child Code Example of Child Code

Smell
Visual
$\begin{aligned} & \text { Parent Code: } \\ & \text { Actions } \\ & \text { taken }\end{aligned}$

\section{Child Code Example of Child Code} ...I have seen that they
school grounds or to the
Example of Child Code

The smell of sewage in the air is disgusting

31)

\begin{tabular}{|c|}
\hline $\begin{array}{l}\text { \# of } \\
\text { Parents } \\
\text { Citing }\end{array}$ \\
\hline \\
\hline
\end{tabular}

16

3

\begin{tabular}{l} 
Response to \\
SSOs \\
(general) \\
$\begin{array}{l}\text { Response } \\
\text { taken by self }\end{array}$ \\
$\begin{array}{l}\text { Parent Code: } \\
\text { Affective } \\
\text { responses }\end{array}$ \\
\hline
\end{tabular}

\section{Child Code Example of Child Code}

smells were not as bad but not seeing signs up and area barricades just make you think the worse and wonder how secure our kids are

6 0

0
stay away from the area

\begin{tabular}{llll} 
Child Code & Example of Child Code & $\begin{array}{l}\text { \# of } \\
\text { Parents } \\
\text { Citing } \\
\text { School }\end{array}$ & $\begin{array}{l}\text { \# of } \\
\text { Staff } \\
\text { Citing }\end{array}$ \\
$\begin{array}{l}\text { Upset } \\
\text { feelings }\end{array}$ & $\begin{array}{l}\text { I have observed only smells. Kinda makes you feel like you're in a } \\
\text { dirty city street. Let's just say I opted for rural life for a reason... that } \\
\text { was somewhat defeated in this aspect. I've since bought one water } \\
\text { filter and have researched other methods of filtration }\end{array}$ & 6 & 2 \\
\hline $\begin{array}{l}\text { Not feeling } \\
\text { updated }\end{array}$ & $\begin{array}{l}\text { really bad smell. I really don't know what the school has done } \\
\text { because they really don't keep people informed who don't live in } \\
\text { Naco }\end{array}$ & 2 & 0 \\
\hline
\end{tabular}

*answer was translated from Spanish to English 
Table 6

Themes reported by parents, and teacher and principal surveys (school staff) when asked: "Please describe your concerns".

\section{Parent Code: None stated}

\section{Child Code \\ Example of Child Code}

\# of
Parents
Citing

$(\mathrm{N}=31)$
\# of School Staff Citing

$(N=7)$

4

9
1

1

Parent Code:

Nuisance

Child Code $\quad$ Example of Child Code

\# of

Parents

Citing

$(\mathbf{N}=31)$

\# of School Staff Citing

$(\mathrm{N}=7)$

Contamination Water contamination

4

2

Parent Code:

Consequences

Child Code Example of Child Code

Typhoid fever, Hepatitis A, Salmonella, Giardias, Gastroenteritis.

To children

The contamination that can affect all the kids*

Safety

The school being so close to it and having our children or the community being ill from it

To property

water contamination, property damages. and threatening public health

\# of

Parents

\# of School

Citing

$(\mathrm{N}=31)$

$(\mathrm{N}=7)$

$5 \quad 2$

7

0

4

0

2

0

Parent Code:

Finding a solution

Child Code

Example of Child Code

$\begin{array}{ll}\begin{array}{l}\text { \# of } \\ \text { Parents } \\ \text { Citing }\end{array} & \begin{array}{l}\text { \# of School } \\ \text { Staff Citing }\end{array} \\ (\mathrm{N}=31) & (\mathrm{N}=7)\end{array}$

Desire to find a

That the problem gets fixed*

2

0 


\subsection{Risk Communication}

Figure 8 illustrates responses from parents and school staff regarding their awareness of sewage overflows within the past year. Thirty-two percent of parents mentioned they had not been aware of these events which may relate to some parents' expressed frustration with lack of communication. Half of teacher respondents said they had been aware, while the other half cited "no" (33\%) and "sometimes" (17\%). Qualtrics software allowed for skip-logic features which directed participants who answered "yes" to indicate the different way(s) of how they had been notified of these events. The top three forms of communication that were cited were: media (television, radio, and Facebook), school announcements, and word of mouth (Fig. 9). Furthermore, nine parents indicated they had found out after the event happened (hours later: $33 \% ; 1-3$ days later: $44 \%$; 1 week after: $11 \%$; and weeks after: $11 \%$ ).

As stated in the project's objectives and cited as a need per parent survey answers, tangible materials will be created specifically to address the questions and preferences of the Naco Elementary School community. In an effort to effectively disseminate this information, parents were asked if they would be interested in receiving information regarding environmental health, to which $62 \%$ replied "yes" and $38 \%$ responded "no". Those who answered "yes" indicated their top three choices to receive this informaton as school announcements, text messages, and county public announcements (See Fig. 10). No association was found between primary language and desire to receive environmental health information, or preferred communication methods.

Improving risk communication and sharing information on preventative actions that can be taken by school staff during SSO events is also of upmost importance; $25 \%$ of teachers $(n=2)$ indicated they take steps to avoid tracking soil into their classroom. One teacher indicated they do this by asking students to clean their shoes before coming into the classroom. Furthermore, the principal noted he is not aware of any protocols that the school follows during SSOs, although he is aware of them and described smelling sewage at least 23 times a month. Their preferred form of communication is email, while phone calls, text messages, and brochures got mentioned equal number of times (Fig. 11).

\section{Discussion}

Risk assessment studies often use human behavior parameter values from the peer-reviewed literature or published by regulatory agencies (Balderrama-Carmona et al., 2014; Clarke et al., 2017; Katukiza et al., 2014). Examples of human behavior and consumption parameters include: soil and drinking water ingestion values for adults and children, consumption of different food types, and volume of water swallowed during various water activities. However, studies have insufficiently addressed whether these human behavior parameter values are, in fact, transferrable from one geographic location to another. This is an important and critical issue given that the majority of exposure studies are conducted for adults or in Western countries and limited data exists for developing countries. For example, adult and children exposure factors handbooks published by the US EPA are used globally in risk assessment studies due to a lack of country-specific values, which is the case in Mexico. Additionally, using point estimate assumptions may not capture cultural nuances that affect exposure (Ashbolt et al., 2010; Choi et al., 2011; Medgyesi et al., 2019; Verbyla et al., 2016; Verhougstraete et al., 2020;). In response, ethnographic methods such as surveys, phone and informal 
interviews, dietary assessments, and direct participant observations have been used in risk assessment studies to fill this knowledge gap and gather exposure data that is representative of the location and culture and in return, provide more site-specific health-based targets and solutions (Ashbolt et al., 2010; Manjon et al., 2019; Verbyla et al., 2016).

In this study, parents and teachers of Naco Elementary were asked about students' hand/object-to-mouth behavior. Compared to values reported by the US EPA (2011), Naco Elementary parents reported lower hand/object-to-mouth frequency for children ages 4-6. However, hand-to-mouth frequency for 7-11 year olds $(0-15)$ was similar to the median value (12.6) reported in Beamer et al. (2012) study on oudoor microactivity in 7-12 year olds. It is note worthing that ,parents did not report any object-to-mouth activity for this same age range, while the US EPA and Beamer et al., report drasticallydifferent values (1.9 and 35.6 respectively). While the US EPA does not report on mouthing frequency for 12-16 year olds, Naco Elementary parents report a wider hand-to-mouth frequency range (0-30) compared to other age groups (Table 7). This reinforces the suggestion that US EPA current guidelines may not be protective enough for children 6 years and older (Beamer et al., 2012).

Table 7

Comparison of parent's reported observations to those in the literature. Parents reported the frequency ranges, not exact values. Units are events/hour.

\begin{tabular}{|c|c|c|c|c|c|c|c|c|c|}
\hline & \multicolumn{3}{|c|}{ 4-6 years } & \multicolumn{3}{|c|}{ 7-11 years } & \multicolumn{3}{|c|}{$12-16$ years } \\
\hline & $\begin{array}{l}\text { Beamer } \\
\text { et al., } \\
2012^{\wedge}\end{array}$ & $\begin{array}{l}\text { US } \\
\text { EPA, } \\
\text { 2011* }\end{array}$ & $\begin{array}{l}\text { This } \\
\text { Study }\end{array}$ & $\begin{array}{l}\text { Beamer } \\
\text { et al., } \\
2012^{\wedge}\end{array}$ & $\begin{array}{l}\text { US } \\
\text { EPA, } \\
2011 *\end{array}$ & $\begin{array}{l}\text { This } \\
\text { Study }\end{array}$ & $\begin{array}{l}\text { Beamer } \\
\text { et al., } \\
2012^{\wedge}\end{array}$ & $\begin{array}{l}\text { US } \\
\text { EPA, } \\
2011 *\end{array}$ & $\begin{array}{l}\text { This } \\
\text { Study }\end{array}$ \\
\hline Hands & NA & 15 & 0 & 12.6 & 7 & $0-15$ & NA & NA & $0-30$ \\
\hline Toys & NA & 10 & 0 & 0.0 & NA & 0 & NA & NA & 0 \\
\hline Natural objects & NA & NA & 0 & 0.0 & NA & 0 & NA & NA & 0 \\
\hline $\begin{array}{l}\text { All } \\
\text { objects/surfaces }\end{array}$ & NA & NA & 0 & 35.6 & 1.9 & 0 & NA & NA & 0 \\
\hline \multicolumn{10}{|c|}{ ^ Median values are reported as recommended by the authors. } \\
\hline \multicolumn{10}{|c|}{$\begin{array}{l}\text { *US EPA age groups }(3<6,6<11,11<16) \text { were adjusted to fit with the age groups used in this study. US } \\
\text { EPA outdoor frequency mean values are reported here. }\end{array}$} \\
\hline \multicolumn{10}{|c|}{ NA $=$ Not Applicable } \\
\hline
\end{tabular}

Children's tendency to play on the floor indoors, on the ground outdoors, and deliberate hand-to-mouth movements may result in significant quantities of soil being ingested. Furthermore, rate of contact (number per unit time) to facial membranes (i.e. lips) presents an important non-dietary ingestion exposure through hand and mouthing contacts with fomites which can result in increased risk of infectious diseases (Beamer et al., 2011; Nicas and Best, 2008). The US EPA Child-Specific Exposure Factors Handbook (2008) describes three general approaches to studying children's mouthing behavior: real-time hand recording by trained observers; video-transcription methodologies, as used in Beamer et al., (2012), which are the most costintensive but carry the least amount of uncertainty as footage is translated by a computer software or trained 
videographers; and questionnaires which rely on memory recall and are the most cost-efficient, but carry a greater degree of uncertainty. Understanding soil, mouthing, and hand contact patterns is an important part of estimating children's overall exposures to environmental chemicals and infectious disease transmission (Beamer et al., 2012; US EPA, 2008).

Offensive odors, negative feelings, and concerns regarding water contamination have been cited in previous studies working with communities close to wastewater treatment sites and sewage sludge application sites (Schiffman et al., 2008; Wing et al., 2014). These observations and concerns were also cited multiple times in open-ended survey answers from parents and school staff. Schiffman et al., (2008) proposes eight levels of odor-intensity exposure that range from detection to more severe health symptoms such as irritation and toxicity. Following this scheme and in accordance with our surveys, the relevant odor levels are: odor detection, odor recognition, and odor annoyance. No parents reported specific health symptoms. However, in Ambos Nogales, border towns approximately 60 miles west of Ambos Nacos that also experience frequent SSOs, a local school has reported odor-related nausea and health symptoms by one of its students. Waste disposal challenges can serve as venues for pathogen and toxicants exposure. Systematic exposure and disease surveillance require further study to better quantify health symptoms due to various exposures affecting residents of impacted areas (Schiffman et al., 2008; Wing et al., 2014). Waste management is a critical issue that continues to be acknowledged in environmental binational goals.

Approximately half of parent respondents do not have or are not sure about any concerns regarding SSOs. A similar percentage indicated no changes are made to their daily routine during these events. Recurrent SSOs are common in Ambos Nacos and along many US-Mexico border towns which may lead to a normalization of the problem where it is seen as a routine part of life, especially when more pressing issues are at hand (Robles-Morua et al., 2011). Informal languages and loose terms were often used to describe SSOs or concerns indicating possible gaps in knowledge in the cause, potential contaminants, and hazards of SSOs. Misunderstanding of the problem at hand can distort risk perception which is an important part of vulnerability (Crona et al., 2008; Robles-Morua et al., 2011). In a one-page flyer plain language was used to address causes of SSOs and associated health risks along with suggestions to inform personal decision making on safe practices during SSOs. Furthermore, the flyer addresses parents' concerns with drinking water quality since some parents mentioned switching their water source during SSOs- an action cited by other residents in border town risk perception studies (Caldeira et al., 2011; Robles-Morua et al., 2011). However, it is important to note that although public drinking water is regularly monitored in $\mathrm{Naco}, \mathrm{AZ}$, this might not be the case for residents in Naco, Sonora or for private drinking wells.

While survey questions were designed to broadly capture knowledge, awareness, and perceptions of SSOs in Ambos Nacos, evaluating risk comprehension requires a variety of questions and approaches that examine beliefs, which encompass intellect and emotion, that drive behaviors and decision-making related to a hazard (Byrd et al., 1997; Weinstein, 1999). Although no association was found between household language preference and expressed concern regarding SSOs, trust in the respective country's government agencies reponsible for wastewater management could affect the outlook on these events and risk perception. Beliefs about hazards are strongly influenced by social and cultural contexts, which in a border rural public school these contexts are complex as many families have roots in both countries and constantly move between the two (Byrd et al., 1997; Crona et al., 2008;). 
Six parents (19\%) mentioned seeing "the government/they" take action during SSO events, and one parent mentioned CHSS especifically. During the SSO events in 2018, CHSS responded by taking actions to monitor environmental contamination, prevent public health consequences, communicate to different stakeholders, and obtain necessary resources to fully address the problem at hand (Table 8). Belief and trust in the government is increased when the community sees the government reacting to a problem (Robles-Morua et al., 2011). Building on this trust for effective risk communication is important as our objective is to present parents and school staff with preventive action steps through education and awareness efforts. Although students do not seem to commonly congregate or participate in activities in locations that have been impacted by sewage, per the teacher survey responses, taking steps to avoid bringing contamination into the classroom (i.e. avoid tracking soil) could be a simple preventative action. A streamlined risk communication plan is outlined in Fig. 12 that considers the party's preferred mode of communication (in italic), along with information that they have identified as necessary to inform risk. This is especially important since only two teachers mentioned taking preventative action steps and the principal noted not being aware of a protocol during SSO events.

Table 8

Summary of actions taken by Cochise Health and Social Services during the series of SSOs in 2018.

\begin{tabular}{|l|l|}
\hline Environmental monitoring & \\
\hline & Surface water \\
\hline & Private wells \\
\hline Public health & Surnking water \\
\hline & Vaccination clinics provided to Naco, AZ residents \\
\hline Berms were used to contain sewage effluent \\
\hline Chlorine tablets added for disinfection \\
\hline Signs placed around impacted areas \\
\hline Seeking additional resources & Incident reported to National Response Center \\
\hline & Townhall meeting held for local residents \\
\hline & Secured funds to address emergency situation \\
\hline & Partnership established with the University of Arizona \\
\hline
\end{tabular}




\subsection{Limitations}

As with any study, there are limitations in the survey design, distribution, and results. Questions related to hand/object-to-mouth behavior could be laden with measurement errors as a result of recall bias, a desire to report socially desirable behaviors, problems with question wording, and differences in interpretation and term definitions (Bauza et al., 2018; US EPA, 2008). Although no health related symptoms were reported in openended questions by parents, additional questions listing specific symptoms could have aided in memory recall and improved accuracy. Furthermore, in an effort to keep questions simple and clear, we might have missed details that capture a more thorough risk perception. In addition, because parents were approached during school events, there were conflicting priorities and they were often pressed on time. Because surveys were distributed at school events, we missed the opportunity to survey parents who were not present at such events including those who reside in Naco, Sonora and are unable to attend. This limitation hinders our understanding of how SSOs are percieved by families who primarily live on the Mexican side of the border and whether additional exposures exist for children who regularly walk between Ambos Nacos. Student absenteeism records and clinical data for gastrointestinal related visits could have supplemented to the information gathered by survey.

\section{Conclusions}

Findings from this study suggest a lower hand/object-to-mouth frequency for children ages 4-11, and a wider range of hand-to-mouth frequency for students ages 12-16. Approximately half of parents are not concerned or are not sure about their concerns regarding SSOs, and 32\% reported not being aware of such events. Concerns among parents and school staff included health and safety of their community and children, and water contamination. Responses from parents and school staff also point towards a need for developing better risk communication during such events and the development of actions to safeguard health. To effectively disseminate risk information, we attempted to better understand risk perception among the community. A risk communication plan between CHSS, the school's principal, teachers, and parents is proposed, along with a one-page information flyer designed to increase understanding of SSOs.

Although rural towns are more numerous along the US-Mexico border, most environmentally-related risk perception and exposure studies are conducted in the populous urban sister border cities. This study seeks to add to the limited understanding in rural border communities that are affected by waste management challenges. Our findings suggest that a lack of information and understanding around SSOs, contribute to a percieved associated low-risk or uncertainty around these events. Future work should focus on direct collaboration with organizations in Naco, Sonora, to ensure the SSO-related information is socio-culturally appropriate to families living there and is disseminated effectively. Furthermore, given that the transboundary SSOs originate in Sonora, a greater understanding of the structure and challenges of water and sanitation projects in Naco, Sonora is needed. The decentralization of water resource agencies in Mexico has left many Mexican rural towns without resources or technological expertise. Community involvement in water sanitation improvement efforts in rural Mexico has proven successful (Robles-Morua et al., 2007). A similar approach could be beneficial in Naco, Sonora in addition to the involvement of binational agencies and strengthening communication among the local agencies in Ambos Nacos. 


\section{Abbreviations}

Sanitary sewage overflows

SSOs

Cochise Health and Social Services

CHSS

University of Arizona Environmental Science

UA ENVS

\section{Declarations}

\section{Ethics approval and consent to participate}

The study was submitted to the University of Arizona's Human Subjects Protection Program and approved by the University of Arizona's Institutional Review Board (IRB). Study participants (principal, teachers, and parents) were consented under the University of Arizona IRB as an approved project. Written consent (hand written or electronically) was obtained by study participants. Children did not participate in this study, thus no parental consent was required.

\section{Consent for publication}

N/A. No individual person's data in any form (including any individual details, images or videos) is included.

\section{Availability of data and material}

Data and materials are available upon request.

Code availability

Code for data cleaning and analysis in $\mathrm{R}$ is provided as part of supplementary information.

\section{Competing interest}

The authors declare that they have no known competing financial interests or personal relationships that could have appeared to influence the work reported in this paper.

\section{Funding}

This work was supported by the Cochise County Health and Social Services (award number 4244490), United States. The funder, Cochise County Health and Social Services, covered study costs. The funding body did not play a role in the study design, collection, analysis, and interpretation of data, or in writing the manuscript.

\section{Authors' contributions}

Study Conceptualization: M.D.R-A. and A.A.M.; Methodology: A.A.M. and M.D.R-A.; Investigation: A.A.M. and D.H.; Formal Analysis: A.A.M.; Validation: A.A.M. and D.H.; Writing-Original Draft Preparation: A.A.M.; Writing- 
Review \& Editing: A.A.M., M.D.R-A., D.H.; Supervision: M.D.R.-A.; Project Administration: M.D.R-A.; Funding Acquisition: A.A.M. and M.D.R-A. All authors have read and approved the manuscript.

\section{Acknowledgements}

Research for this paper was supported by the Cochise Health and Social Services, and the Climate Assessment for the Southwest fellowship. We would like to thank Shana Sandhaus for assistance in qualitative coding. Many thanks to Dr. Abel Morado and Mr. Tim Mayclin for facilitating collaboration with school teachers and parents. Lastly, special thank you to all the teachers and parents for their time and consideration.

\section{References}

Anides Morales AL, Gerba CP, Reynolds KA, Ramirez-Andreotta MD. (2020) Risk Assessment in Soil Fecal Contamination Using Literature and Location Based Data. Unpublished data.

Austin D. Partnerships, Not Projects! Improving the Environment Through Collaborative Research and Action. Human Organization. 2004;63(4):419-30. https://doi.org/10.17730/humo.63.4.v7x1t5mwqf1xi3v.

Bauza V, Byrne DM, Trimmer JT, Lardizabal A, Atiim P, Asigbee MAK, Guest JS. Child Soil Ingestion in Rural Ghana - Frequency, Caregiver Perceptions, Relationship with Household Floor Material and Associations with Child Diarrhoea. Tropical Med Int Health. 2018;23(5):558-69. https://doi.org/10.1111/tmi.13050.

Beal T. Bisbee asks aid in sewer threat. Arizona Daily Star. August 1977;5:A3. https://www.newspapers.com/clip/32334001/naco-article-az-daily-star-851977/.

Beamer P, Luik CE, Canales RA, Leckie JO. Quantified Outdoor Micro-Activity Data for Children Aged 7-12-Years Old. J Eposure Sci Environ Epidemiol. 2012;22(1):82-92. https://doi.org/10.1038/jes.2011.34.

Byrd TL, VanDerslice J, Peterson SK. Variation in environmental risk perceptions and information sources among three communities in El Paso. Risk: Health Safety Environment. 1997;8(4):355-72.

Caldeira F, O'Rourke MK, Gil C. Water and wellness in two colonias of Nogales, Sonora, Mexico. International Journal of Health Wellness Society. 2011;1:193-212. https://doi.org/10.18848/21568960/CGP/v01i03/58091.

Callegary JB, Minjárez Sosa I, Tapia Villaseñor EM, Dos Santos P, Monreal Saavedra R, Grijalva Noriega FJ, Huth AK, Gray F, Scott CA, Megdal SB, Oroz Ramos LA, Rangel Medina M, Leenhouts JM. (2016) San Pedro River Aquifer Binational Report: International Boundary and Water Commission, 170 p. https://www.ibwc.gov/Files/San_Pedro_River_Binational\%20Report_013116.pdf.

Choi H, Park MS, Lee HM. Hand Surface Area as a Percentage of Body Surface Area in Asian Children: A Pilot Study. Burns. 2011;37(6):1062-6. https://doi.org/10.1016/j.burns.2011.03.010.

Creswell JW, Poth CN. (2017) Qualitative Inquiry and Research Design: Choosing Among Five Approaches. SAGE Publications. 
Environment and Water Committee of the Arizona-Mexico Commission. (2016) Arizona-Sonora Environmental Strategic Plan 2017-2021. https://static.azdeq.gov/pub/obep_strat_plan.pdf.

Garfin G, Jardine A, Merideth R, Black M, LeRoy S. Assessment of Climate Change in the Southwest United States. Washington DC: Island Press; 2013.

Gerba CP, Pepper IL. Microbial Contaminants. In: Gerba CP, Brusseau ML, Pepper IL, editors. Environmental and Pollution Science. 2nd ed. San Diego: Elsevier Science \& Technology; 2006. pp. 144-69.

Good Neighbor Environmental Board. (2016) Climate Change and Resilient Communities Along the U.S.Mexico Border: The Role of the Federal Agencies https://nepis.epa.gov/Exe/ZyPDF.cgi/P100QFGF.PDF? Dockey=P100QFGF.PDF.

Lara-Valencia F, Giner ME. Local Responses to Climate Change Vulnerability Along the Western Reach of the US-Mexico Border. Journal of Borderlands Studies. 2013;28(2):191-204. https://doi.org/10.1080/08865655.2013.854656.

Littin GR. (1987) Groundwater resources of the Bisbee-Naco area, Cochise County, Arizona: U.S. Geological Survey Water-Resources Investigations Report 87-4103, 34 p.

https://doi.org/10.3133/wri874103.

May ML, Bowman GJ, Ramos KS, Rincones L, Rebollar MG, Rosa ML, Saldana J, Sanchez AP, Serna T, Viega N, Villegas GS, Zamorano MG, Ramos IN. Embracing the Local: Enriching Scientific Research, Education, and Outreach on the Texas-Mexico Border through a Participatory Action Research Partnership. Environmental Health Perspective. 2003;111(13):1571-6. https://doi.org/10.1289/ehp.5771.

Nicas M, Best D. (2008) A study quantifying the hand-to-face contact rate and its potential application to predicting respiratory tract infection. Journal of Occupational Environmental Hygiene 5: 347-52. https://doiorg.ezproxy1.library.arizona.edu/10.1080/15459620802003896.

Robles-Morua A, Mayer A, Durfee M. Community partnered projects: A case study of a collaborative effort to improve sanitation in a marginalized community in northwest Mexico. Environ Dev Sustain. 2009;11(1):197213. http://doi.org/10.1007/s10668-007-9104-5.

Robles-Morua A, Halvorsen K, Mayer A. Waterborne Disease-Related Risk Perceptions in the Sonora River Basin, Mexico. Risk Anal. 2011;31(5):866-78. https://doi.org/10.1111/j.1539-6924.2010.01570.x.

US Environmental Protection Agency (US EPA). (1983) Agreement for the protection and improvement of the environment in the border area. https://www.epa.gov/sites/production/files/201509/documents/lapazagreement.pdf.

US Environmental Protection Agency (US EPA). Child-Specific Exposure Factors Handbook (Final Report). U.S. Environmental Protection Agency, 2008 Washington, DC, EPA/600/R-06/096F, 2008. 
US Environmental Protection Agency (US EPA). Highlights of the Child-Specific Exposure Factors Handbook (Final Report). U.S. Environmental Protection Agency, Washington, DC, EPA/600/R-08/135, 2009.

US Environmental Protection Agency (US EPA). Exposure Factors Handbook 2011 Edition (Final Report). U.S. Environmental Protection Agency, Washington, DC, EPA/600/R-09/052F, 2011.

U.S.-México Border Health Commission (BHC). (2015) Healthy Border 2020: A Prevention \& Health Promotion Initiative. https://www.hhs.gov/sites/default/files/res_2805.pdf.

U.S. Government Accountability Office (US GAO). (2009) Rural Water Infrastructure: Improved Coordination and Funding Processes Could Enhance Federal Efforts to Meet Needs in the U.S.-Mexico Border Region. https://www.gao.gov/products/GA0-10-126.

O'Fallon LR, Tyson F, Dearry A. Improving public health through community-based participatory research and outreach. Environ Epidemiol Toxicol. 2000;2(2-3):201-9.

Ramirez-Andreotta MD, Brusseau ML, Artiola JF, Maier RM, Gandolfi AJ. Environmental Research Translation: Enhancing Interactions with Communities at Contaminated Sites. Sci Total Environ. 2014;497-498:651-64. https://doi.org/10.1016/j.scitotenv.2014.08.021.

Schiffman SS, Walker JM, Dalton P, Lorig TS, Raymer JH, Shusterman D, Williams CM. (2000) Potential Health Effects of Odor from Animal Operations, Wastewater Treatment, and Recycling of Byproducts. Journal of Agromedicine 7(1), 7-81 https://doi-org.ezproxy4.library.arizona.edu/10.1300/J096v07n01_02.

Weinstein ND. (1999) What Does It Mean to Understand a Risk? Evaluating Risk Comprehension. Journal of the National Cancer Institute Monographs 1999(25), 15-20

https://doi.org/10.1093/oxfordjournals.jncimonographs.a024192.

Wing S, Lowman A, Keil A, Marshall SW. Odors from Sewage Sludge and Livestock: Associations with SelfReported Health. Public Health Rep. 2014;129(6):505-15. https://doi.org/10.1177/003335491412900609.

\section{Figures}

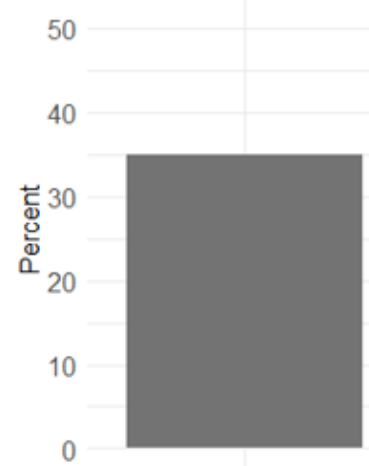

4-6

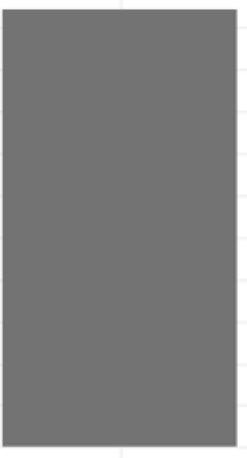

$7-11$ Ages

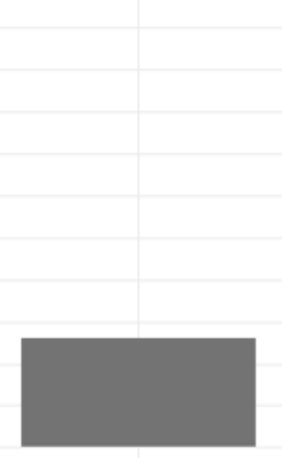

12-16

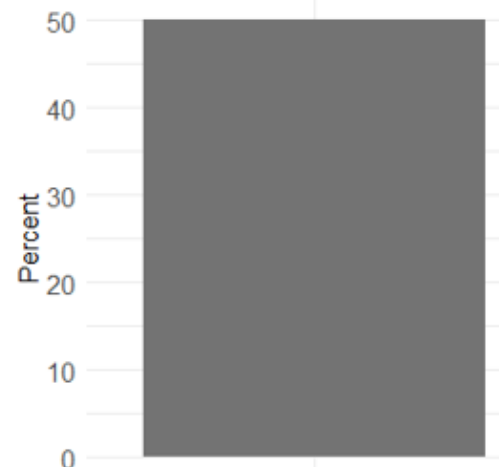

Female

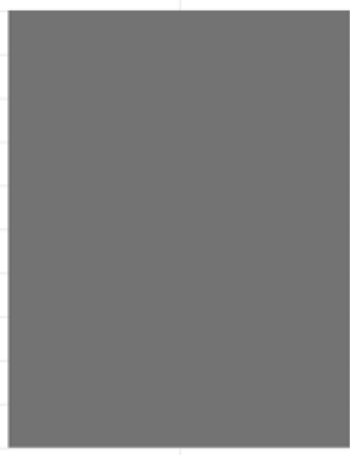

Male 


\section{Figure 1}

Age (1a) and gender (1b) distribution of students as reported in the parent surveys.

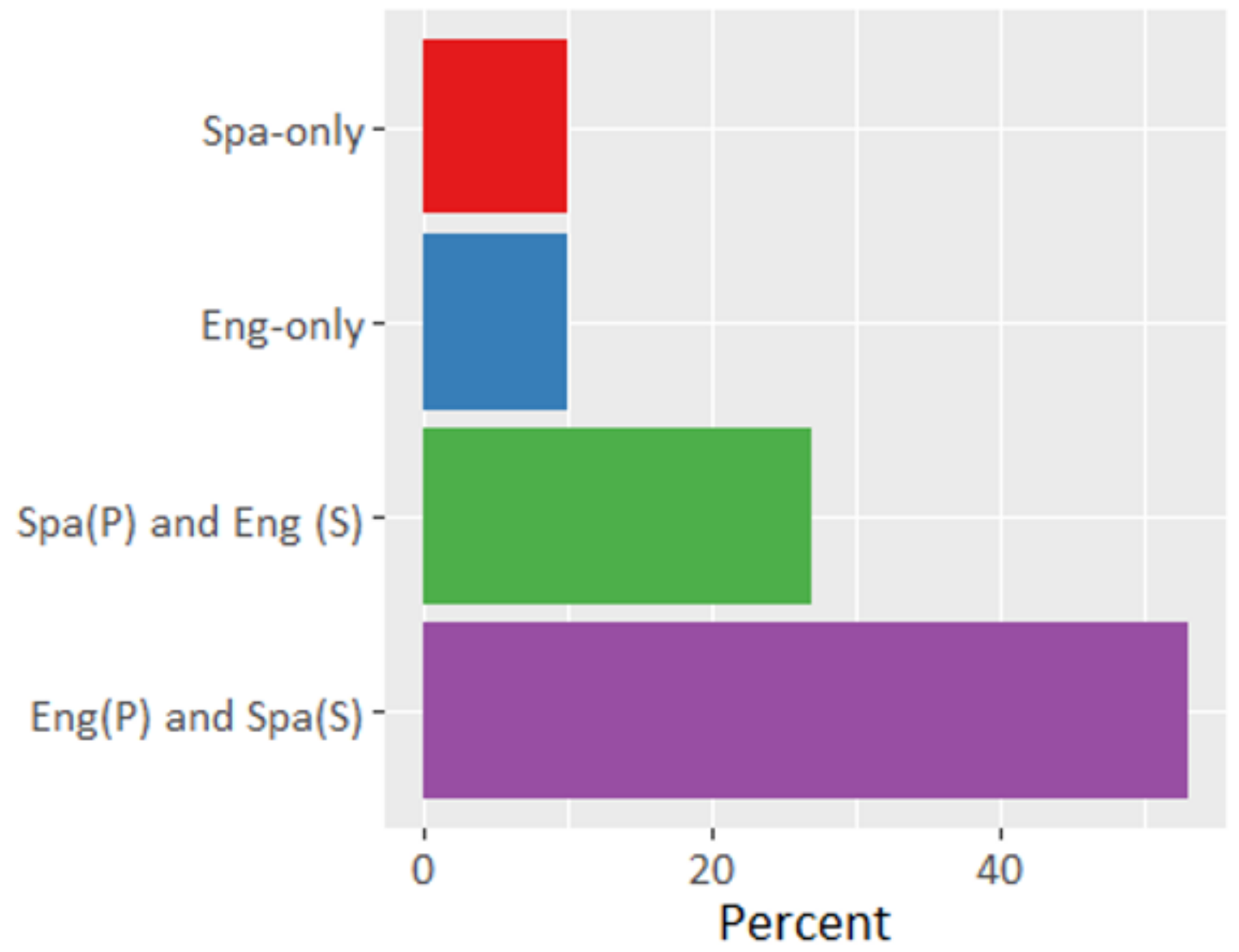

\section{Figure 2}

Language preferences $(P=$ primary; $S=$ secondary language $)$ at home as reported in the parent survey. 


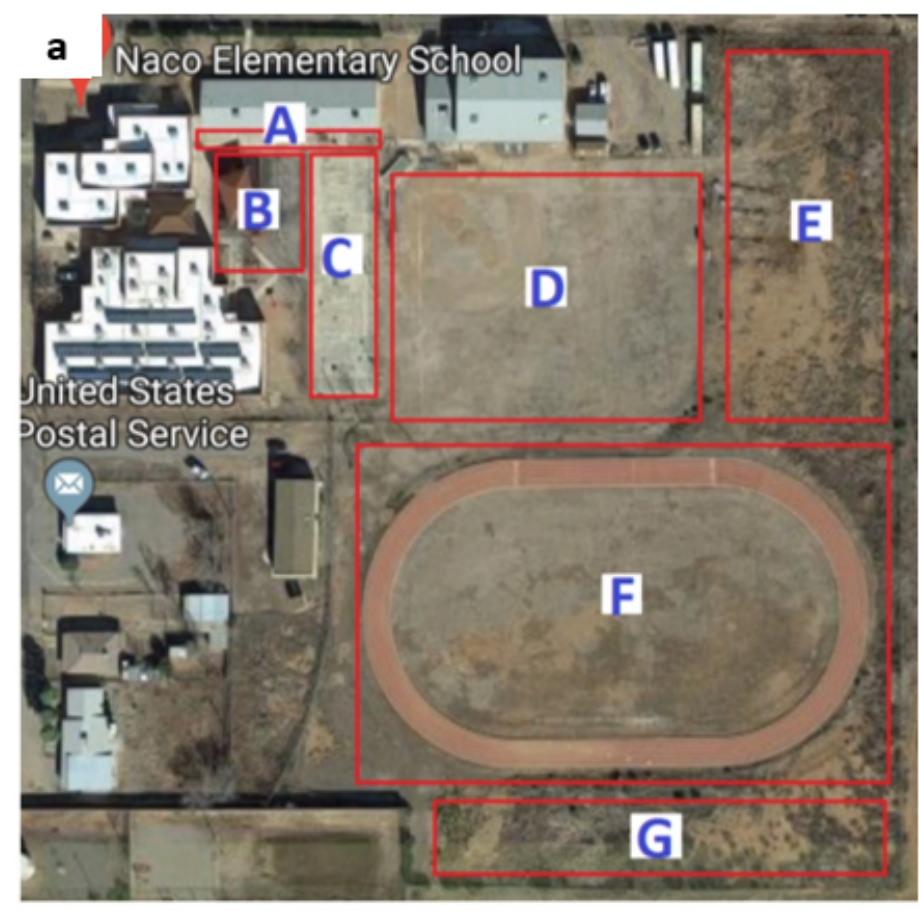

\section{b}

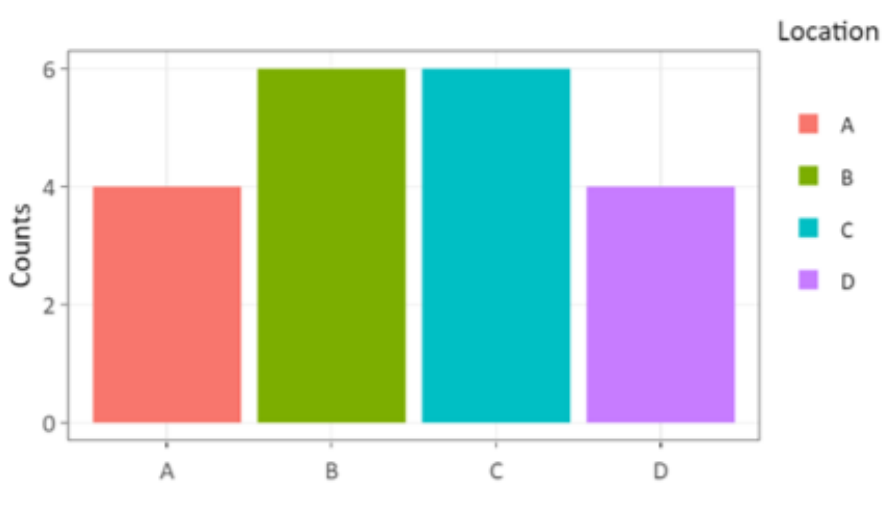

\section{Figure 3}

Annotated map of Naco Elementary School (3a) provided in teacher survey along with teachers' responses $(3 \mathrm{~b} ; \mathrm{N}=8)$ of where students play during lunch time. Map credit: Google Maps. Note: The designations employed and the presentation of the material on this map do not imply the expression of any opinion whatsoever on the part of Research Square concerning the legal status of any country, territory, city or area or of its authorities, or concerning the delimitation of its frontiers or boundaries. This map has been provided by the authors.
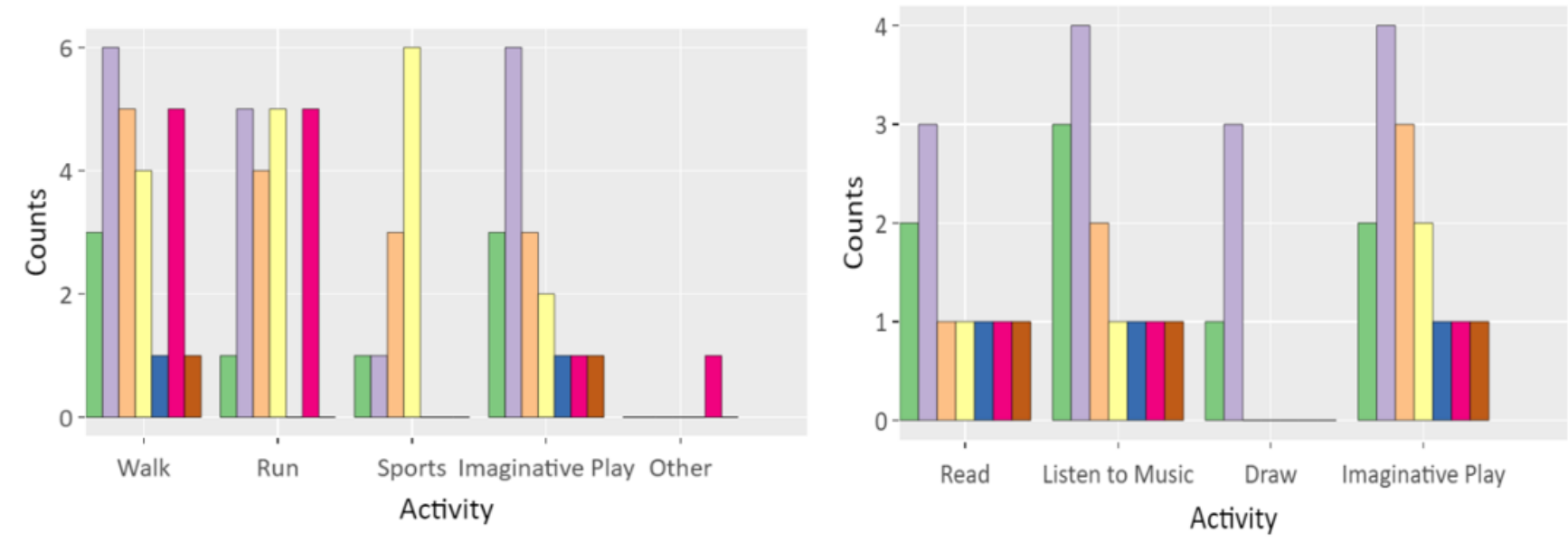

Location

Figure 4 
Given the same map as in Fig. 3, teachers reported where certain physical activities are conducted outside (4a), and where certain passive activities are conducted outside (4b).
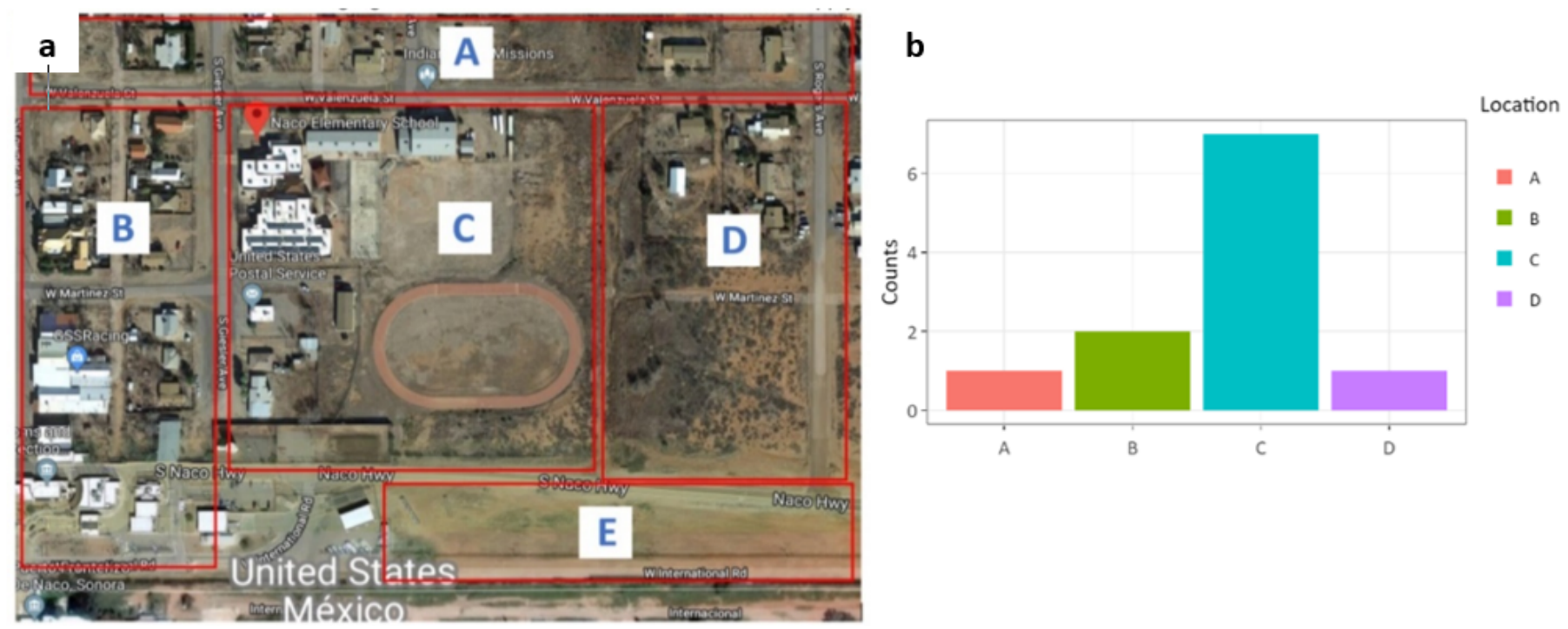

\section{Figure 5}

Annotated map of Naco Elementary School (5a) and teachers' responses ( $5 \mathrm{~b} ; \mathrm{N}=8)$ of where students usually congregate before and after school. Map credit: Google Maps. Note: The designations employed and the presentation of the material on this map do not imply the expression of any opinion whatsoever on the part of Research Square concerning the legal status of any country, territory, city or area or of its authorities, or concerning the delimitation of its frontiers or boundaries. This map has been provided by the authors. 


\section{A) Natural Objects}

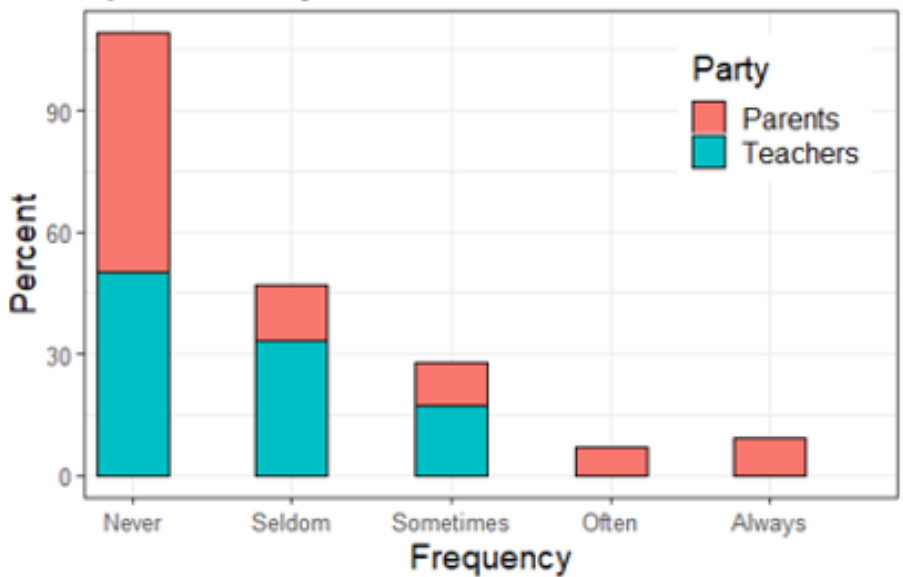

C) Hands

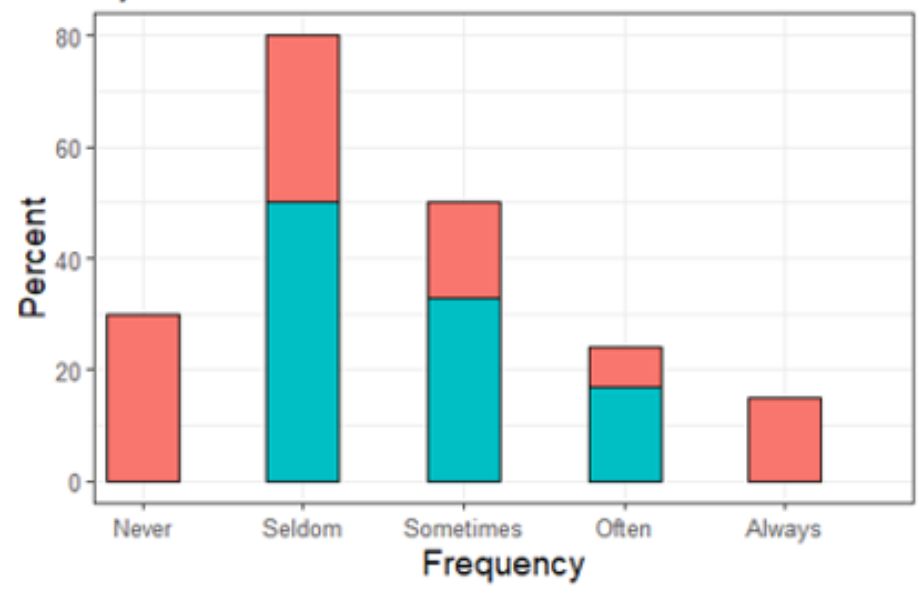

B) Surfaces

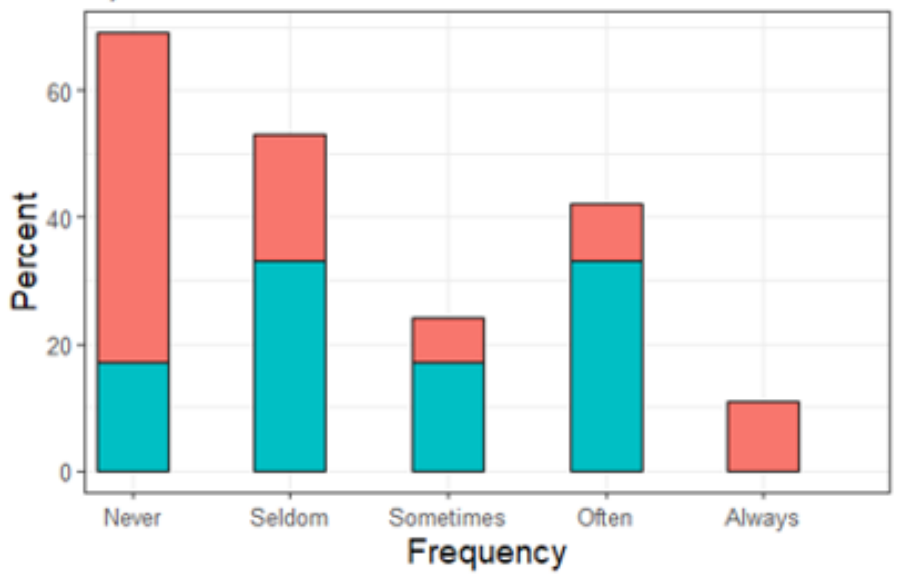

D) Toys

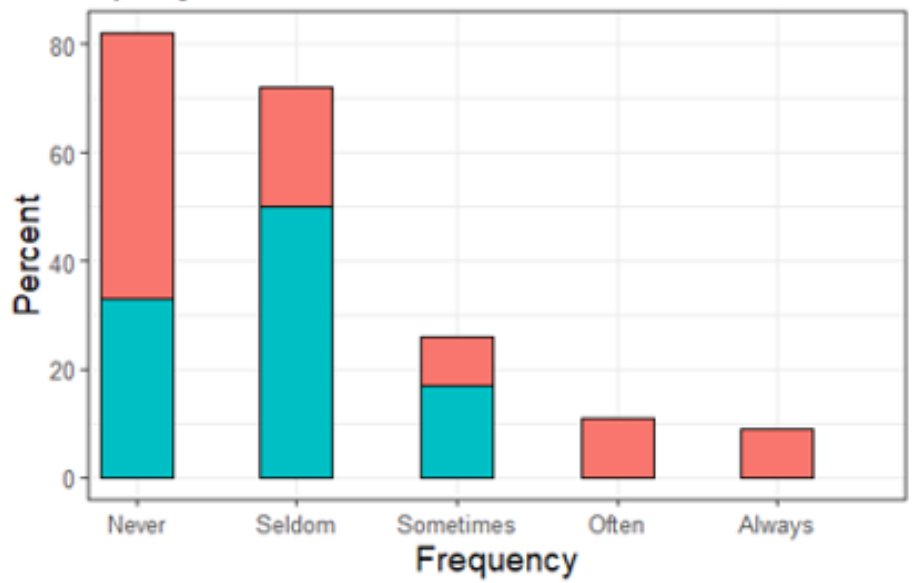

Figure 6

Comparison between hand/object-to-mouth frequency as reported by parents $(\mathrm{N}=31)$ and teachers $(\mathrm{N}=6)$. 


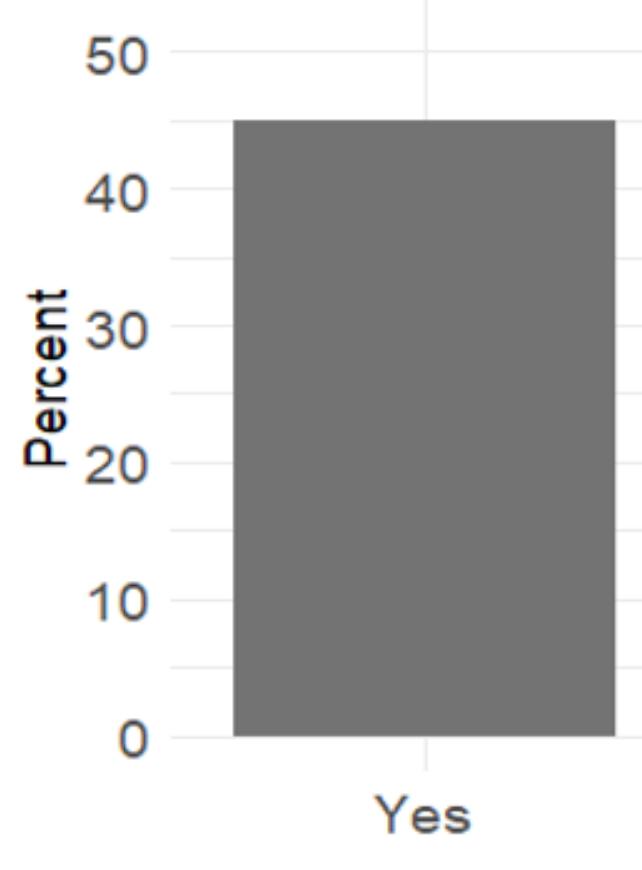

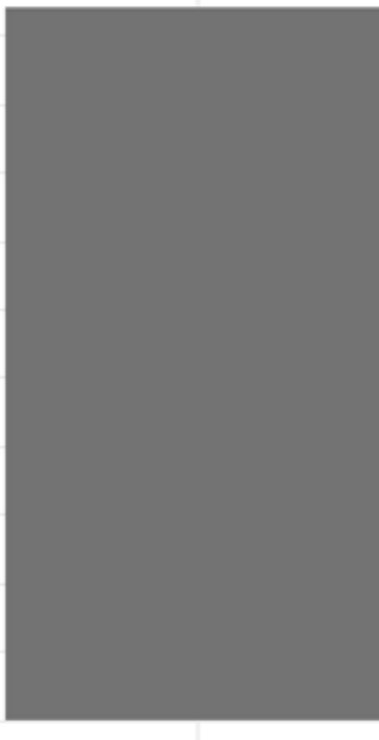

No

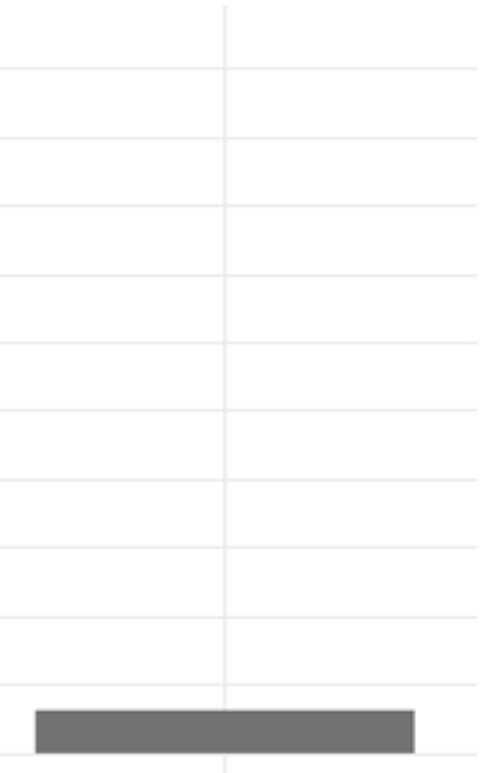

No Response

\section{Figure 7}

Parent's reponse to whether they change anything in their daily routine during a SSO event.

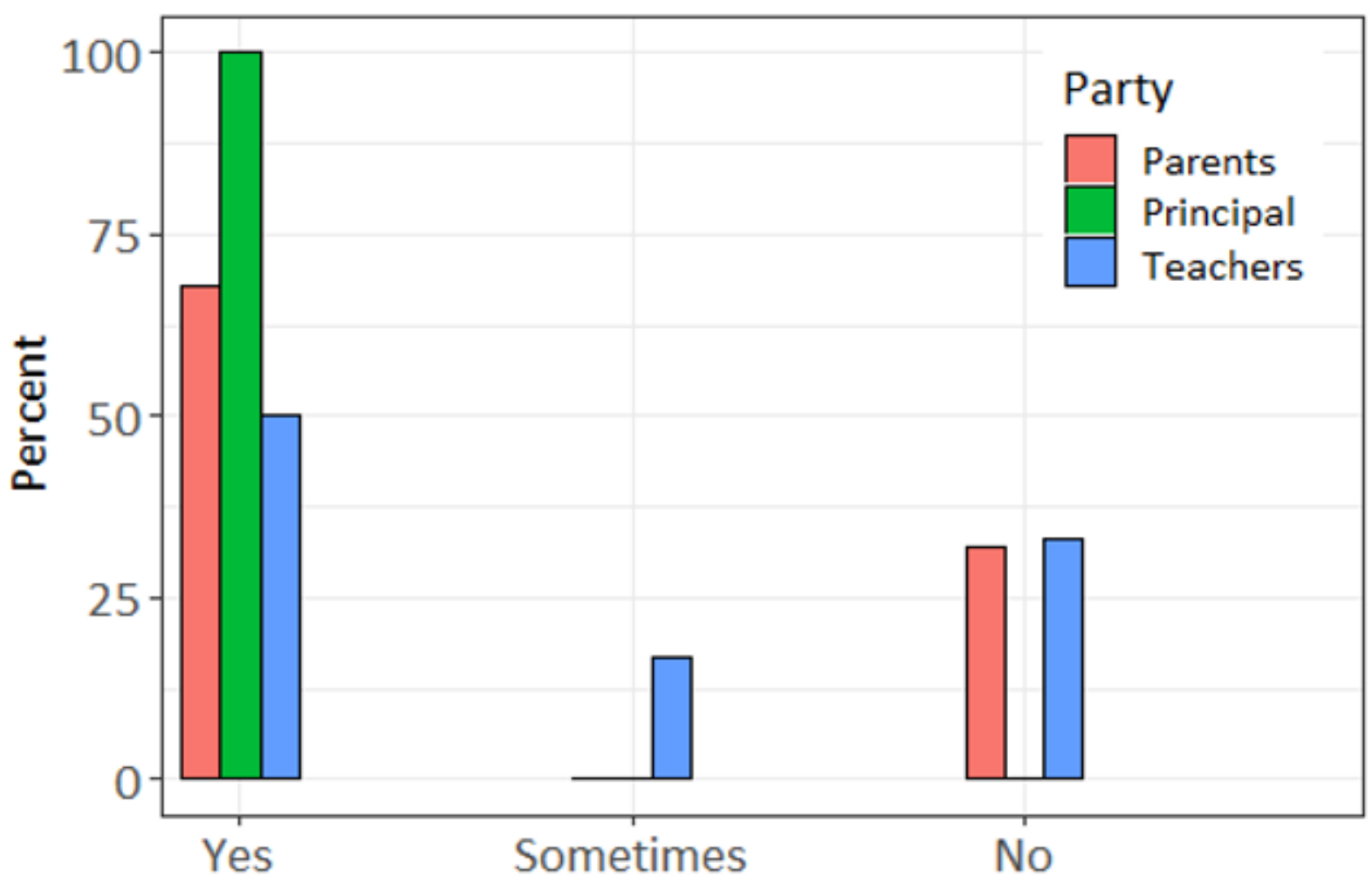


Figure 8

SSO awareness among parents and school staff. (Principal $N=1$; teachers $N=6$; parents $N=31$ ).

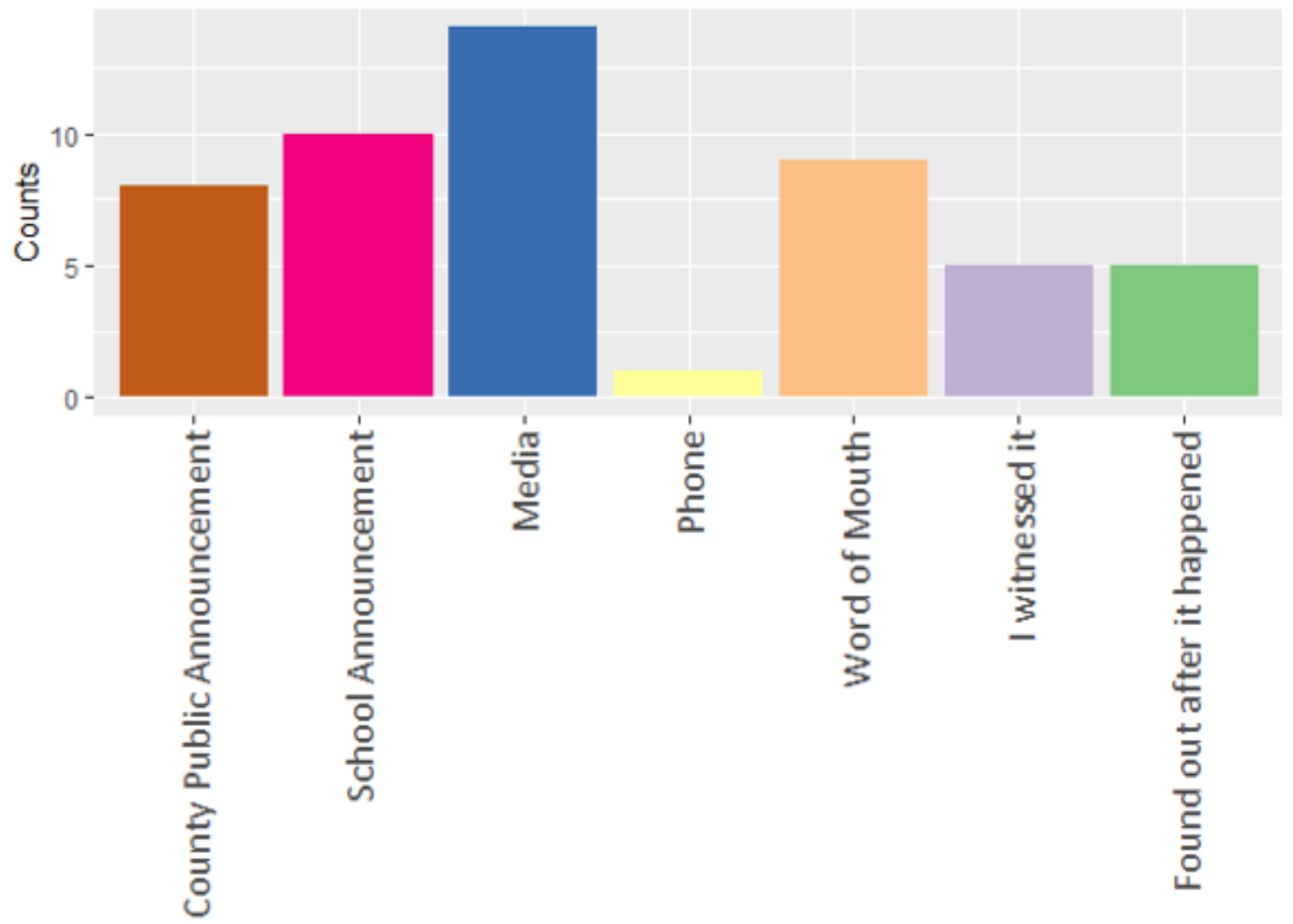

Figure 9

Combined responses (school staff and parents) to the question: "How did you find out a SSO was occurring?". 


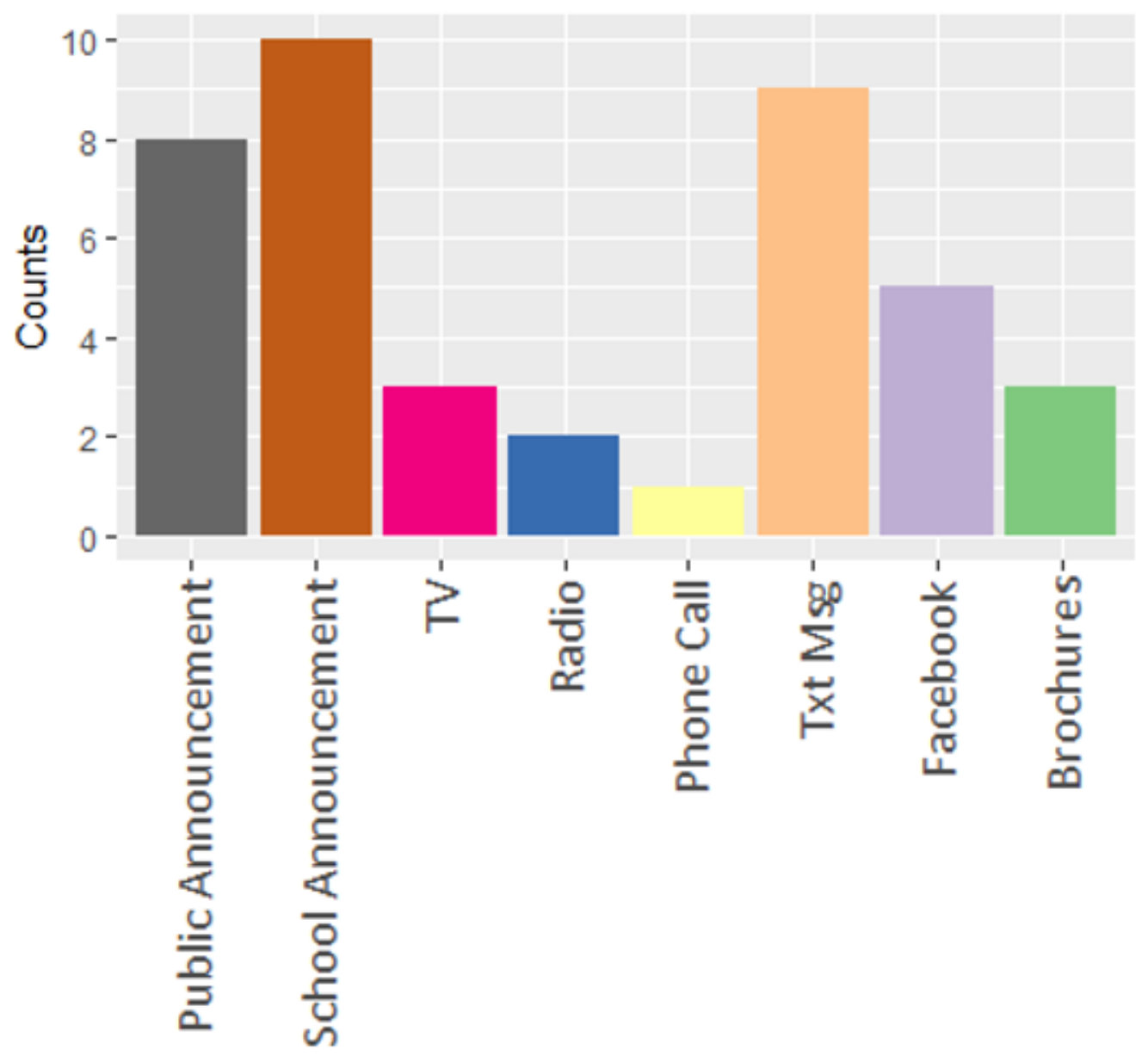

Figure 10

Parents preferences on receiving environmental health $(E H)$ information. 


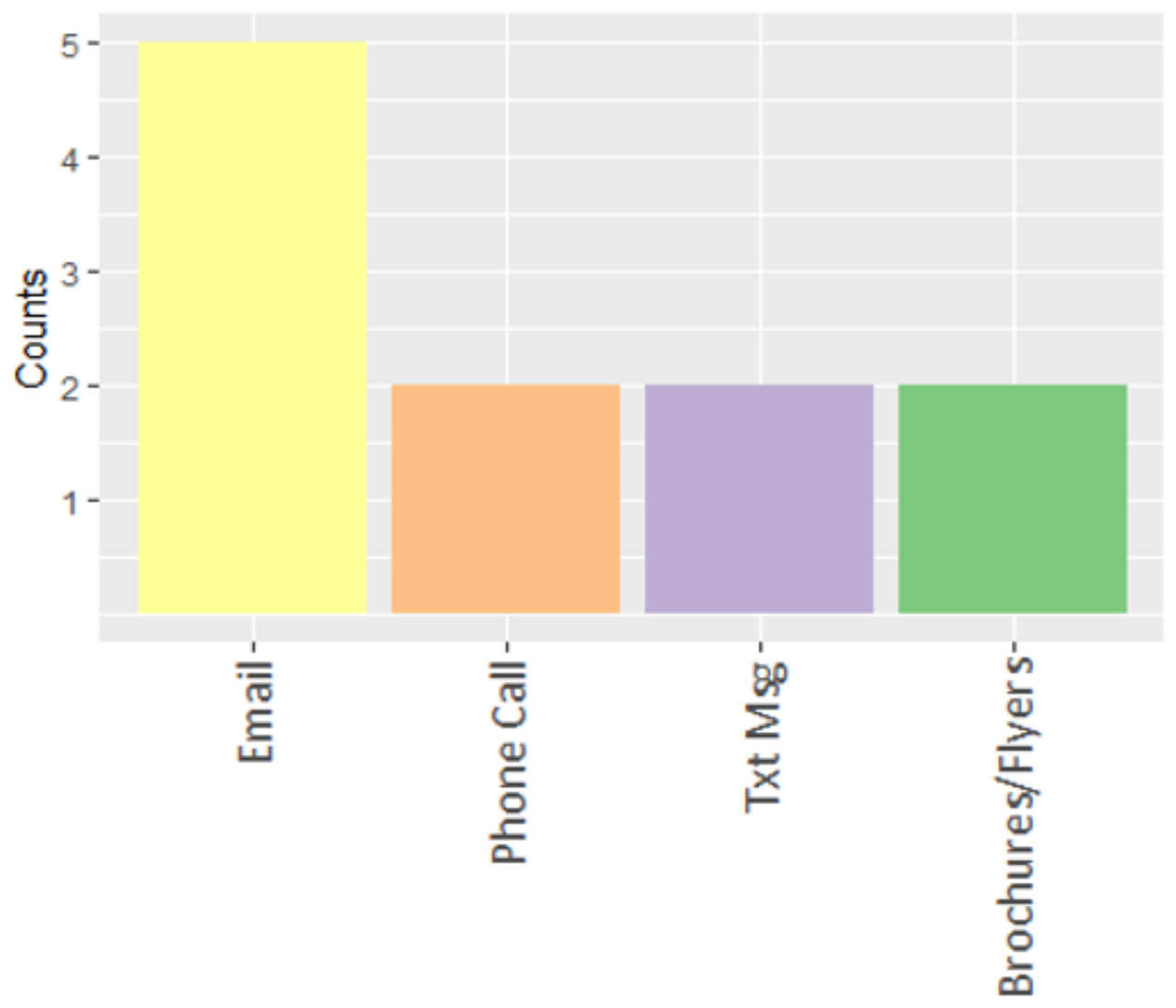

Figure 11

Preferred risk communication among school staff. 


\section{CHSS}

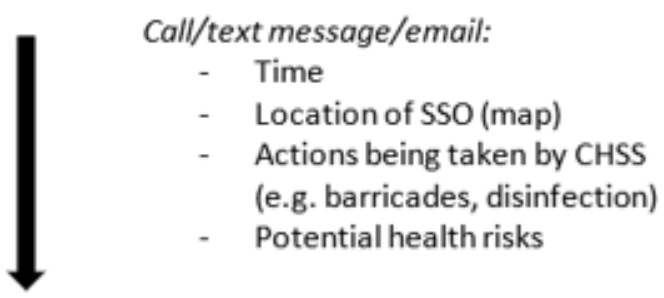

\section{Principal}

Email;

- Same information as above

- Encourage teachers to ask students to dust off shoes before coming indoors, wash hands more often, keep inside, and stay away from the area

- Drinking water quality

Teachers

Email/text message/Facebook:

- Time

- Location of SSO (map)

- Actions being taken (e.g. barricades, disinfection) by CHSS and school

- Recommendations to safeguard family's health

- Drinking water quality

Public announcement in traffic message board

\section{Parents}

\section{Figure 12}

Proposed communication chain during SSO events.

\section{Supplementary Files}

This is a list of supplementary files associated with this preprint. Click to download.

- BehRiskPercepExpHealthSI1.docx

- BehRiskPercepExpHealthSI2.docx

- BehRiskPercepExpHealthSI3.docx

- BehRiskPercepExpHealthSI4.pdf

- BehRiskPercepExpHealthSI5.docx 